\title{
The French Anticolonial Solidarity Movement and the Liberation of Guinea-Bissau and Cape Verde
}

\author{
'It is our armed liberation struggle which \\ will eliminate Portuguese colonialism in \\ Africa, and at the same time put an end \\ to the anti-African complicity of \\ Portugal's allies. This struggle also \\ offers us the advantage, among others, \\ of getting to know in a real way who are \\ the friends and who are the enemies of \\ our people'. Amílcar Cabral ${ }^{1}$
}

Víctor Barros

(PhD in Contemporary Studies from the University of Coimbra and researcher at Institute of Contemporary History, NOVA University of Lisbon)

\author{
vbarros@fcsh.unl.pt
}

\begin{abstract}
The liberation wars in the Portuguese colonies were not merely local processes, circumscribed to the geographical areas where armed combat was taking place. This article sheds light on this phenomenon by examining the ways in which the PAIGC's struggle, combined with Amilcar Cabral's political performance, influenced the activism of anticolonialist committees in France, particularly in Paris. After mapping out the committees' actions and discourses concerning the PAIGC - as well as their broader critique of Portuguese colonialism and authoritarianism - the article analyses a set of cultural artefacts (books, plays, etc) produced by these groups which helped disseminate the Guinean war at an international level. It also discusses the articulation between the committees' demands and their positions vis-à-vis the politics of France and Portugal, as well as their wider denunciation of western imperialism and the Cold War system. The aim is to assess the interplay between domestic and internationalist agendas, demonstrating how, on the one hand, the French committees' rhetoric and actions were influenced by the liberation movements and, on the other hand, the support for the African struggle served a purpose in their political strategy at home.
\end{abstract}

Keywords: French anticolonial solidarity; Support committee; PAIGC liberation struggle; Guinea-Bissau and Cape Verde.

\section{Introduction}

The struggle against Portuguese colonialism in Africa was not an isolated historical process. The reach of African independence movements often transcended the specific geopolitical sites of their armed struggles. This article analyses how the actions of movements struggling for liberation from Portuguese colonialism influenced the creation of anticolonial support committees in Europe, particularly in Paris, France. It 
explores how those movements used French support committees (comités de soutien) to internationalize their national liberation struggles and the African anticolonial revolution as a whole. It further discusses how the support committees themselves appropriated certain themes and terms from the idiom of African liberation in order to contest the French government and establishment. The article thus argues that these African movements impelled the agency of political actors within French civil society, or, in other words, that revolutionary movements from the Global South visibly affected the sociopolitical interactions of actors in Western Europe.

The support committees under analysis were anticolonial solidarity groups, autonomous organizations formed within the civil societies of Western countries in order to encourage and provide political, informational, moral, financial, material and medical support to African liberation movements. The article will begin by assessing how, and to what extent those African movements' actions affected the committees' discursive repertoires and practices. It will then argue that the French militants in Paris adapted the movements' emancipatory principles to the French context, contesting the French Government's provision of diplomatic, economic and military assistance to the Portuguese 'New State' dictatorship (Estado Novo) in its prosecution of wars in Angola, Guinea-Bissau and Mozambique (1961-74). They further reformulated those principles to contextualise the liberation struggle in international terms and thus increase its visibility among French public opinion, to demand individual and collective support for the African movements and, finally, to denounce the West's broader role in perpetuating Portugal's colonial wars. In support of this argument, the article will highlight how cultural artefacts (books, films, information bulletins, newspapers, etc) were mobilized as mechanisms for the international dissemination of the struggles' political messages.

In particular, this article will focus on the case of the African Party for the Independence of Guinea and Cape Verde (PAIGC), under Amílcar Cabral's leadership, and its relation with French militants' solidarity. Cabral was always keenly aware of the strategic advantages of extending the liberation struggle's reach. ${ }^{2}$ The PAIGC's extensive diplomatic interactions with several Third World, Eastern and even a few Western governments enabled productive relationships through which the PAIGC obtained military materiel, humanitarian aid and a growing degree of international legitimacy ${ }^{3}$. Yet Cabral also courted non-state agents, adding a widespread network of anticolonial militants behind the PAIGC's cause. In March 1963, two months after the 
beginning of the armed insurrections in Guinea-Bissau, Cabral held a public press conference in Paris where he discussed the need for various modalities of support, stressing the key role of international solidarity. ${ }^{4}$

This article thus contributes to the ongoing examination of the role of transnational anticolonial solidarity networks in independence struggles in general and in the Southern African liberation in particular. ${ }^{5}$ The movements fighting for independence in Portugal's African colonies are a particularly revealing case study, as they acted strategically to mobilise transnational resources for national liberation. ${ }^{6}$ The ensuing networks must be viewed not only in the context of the Cold War, but also in light of the influence which anti-imperialist and Third World liberation struggles had on the radical Left in many Western countries during the 'long 1960s'. 7 For example, Tramor Quemeneur notes that the French anticolonialists who supported the Algerian war for independence (1954-62) also offered pronounced support to the movements of Portugal's African colonies. ${ }^{8}$ As Benjamin Stora asserts, at the moment Algeria achieved independence, the Third-Worldism inspired by Frantz Fanon's thought was at its peak. ${ }^{9}$ Throughout the $1960 \mathrm{~s}$, anticolonial and anti-imperialist militants within and outside Europe forged transnational solidarity with Third World movements and their demands for liberation. Here the term 'solidarity' relates to the specific historical circumstances and practices of those civil society actors who worked to bring the movements' perspectives and motives into the public arena. ${ }^{10}$

The fact that Guinea-Bissau's and Cape Verde's liberation struggle enjoyed the assistance of Paris-based committees was especially noteworthy because, as multiple scholars have demonstrated, the French Government was an important ally in the context of the Estado Novo's colonial wars: besides supplying Portugal with weapons used in these wars, France, a permanent member of the United Nations (UN) Security Council, typically supported Portugal - or at the very least abstained - whenever the UN Assembly tabled resolutions against Portuguese colonialism, with occasional exceptions when it came to cross-border issue affecting Senegal. ${ }^{11}$ As a result, the French Government was itself confronted by anti-imperialist movements and anticolonial solidarity groups. The tension concerning this issue was such that, since February 1966, the French Government prohibited the presence in France of some of the movements' figureheads. Thus, on 24 January 1968, the French police at the Orly Airport in Paris interdicted Amílcar Cabral from entering France. The police apprehended Cabral's documents and sent them to Portugal's political police, leading to 
the detention of PAIGC militants based in Cape Verde, ${ }^{12}$ some of them subsequently incarcerated at the Estado Novo's notorious prison camp in Tarrafal (Santiago Island). ${ }^{13}$

Indeed, recent academic research on the Portuguese empire's final years highlights the wide plurality of international dimensions at play. ${ }^{14}$ Rui Lopes and other scholars have stressed the centrality of the Cold War in order to understand Portugal's strategy of resisting decolonization and maintaining its colonial wars, emphasizing the part that Portugal's Western allies played in the process. ${ }^{15}$ In turn, the role of anticolonial solidarity, along with the criticism levelled by civil society actors at Western powers that were assisting the Portuguese war effort, still requires a more thorough historiographical engagement. With this in mind, this article will shed light on the significance of these informal networks and, in particular, of the anticolonial support committees in France for the research agenda of scholars working on transnational history, social movements, Third-Worldism, anticolonialism, and the history of liberation struggles in connection with decolonization and the ends of colonial empires.

In order to do this, the article draws on printed sources of the time, including the informative bulletins published by the Support Committee for Angola and the Peoples of the Portuguese Colonies (Comité de Soutien à l'Angola et aux Peuples des Colonies Portugaises) and by the National Support Committee for the Liberation Struggle in the Portuguese Colonies (Comité National de Soutien de la Lutte de Libération dans les Colonies Portugaises); newspapers and statements published by individual anticolonial activists; the statements of the PAIGC; documents from France's Department Archives (Archives Départementales de la Seine-Saint-Denis) and from Paris Nanterre University Archive (La Contemporaine); the papers of Amílcar Cabral; books that publicized the Guinean and Cape Verdean liberation struggle in France; and documents from GuineaBissau's National Institute of Studies and Research (Instituto Nacional de Estudos e Pesquisas - INEP).

\section{The formation of the anticolonial support committees}

During the 1960s, numerous events in the Third World catalysed the escalation, at an international scale, of anticolonial consciousness. Western youth was influenced by figures such as Fidel Castro and Che Guevara. The Vietnam war brought tens of thousands of young people to the streets in protest. The political convictions of many young people were also shaped by the liberation movements of Portugal's African 
colonies, whose actions transformed public opinion throughout Europe. ${ }^{16}$ In the case of France, the first committee to oppose the Portuguese colonial wars was created in the aftermath of the initial armed insurrections in Angola, in February 1961. Accounts of the war crossed the Angolan borders and rapidly and persuasively found their way into the French press. ${ }^{17}$ In its fourth volume of 1961, the magazine Présence Africaine expressed its support for Angolan liberation movements, particularly the MPLA (Movimento Popular de Libertação de Angola) and UPA (União das Populações de Angola), both of which sought to lead the struggle for national independence. The African Society of Culture and the Friends of Présence Africaine (a collective composed of writers, artists, African and Antillean intellectuals) published a statement in the same magazine condemning the war against the people of Angola and emphasising the Portuguese authorities' disrespect for one of the principles of the UN Charter, of which Portugal was a signatory, namely the independence of territories and peoples under colonial rule (article 73). They further argued that Portuguese colonialism was ultimately a threat to peace and international security. ${ }^{18}$ This argument was not original: it reproduced ideas first formulated by Amílcar Cabral on 1 December 1960 and on 26 September 1961, when he had used the same words in memoranda sent to the Portuguese Government. On this point, the views of French anticolonialists were clearly aligned with the political thesis of this African revolutionary leader. ${ }^{19}$

The African Society of Culture and the Friends of Présence Africaine called for all of the anticolonial organizations in the world to provide every means of assistance to the Angolan nationalists. They also announced the establishment in France of a collective called the Support Committee for the Angolan People that they claimed was open to all those who cared about justice and liberty, and called upon people all over the world to create similar committees to support the Angolans. ${ }^{20}$ The Présence Africaine's position cannot be disconnected from the relationship that the magazine maintained with students from Portugal's African colonies ${ }^{21}$. Notably, in the early 1950s, the Angolan Mário Pinto de Andrade (future founding leader of the MPLA) had corresponded with Alioune Diop, the Director of Présence Africaine, and gone on to become a member of the magazine's editorial board and Diop's personal Secretary (1954-1958). ${ }^{22}$ The creation of this first support committee in France was a corollary of African transnational anticolonialism and, consequently, of the armed uprising in Angola itself. The solidarity movement initially referred only to the Angolan struggle, but soon their political framework expanded in scope: on 21 November 1962, an official 
document drafted in Paris announced the creation of the Support Committee for Angola and the Peoples of the Portuguese Colonies. ${ }^{23}$

The Conference of Nationalist Organizations of the Portuguese Colonies (CONCP) - an organization that aggregated the independence movements of the Portuguese colonies, founded in Morocco on 18 April 1961 - saluted the creation of this French support committee. The CONCP considered it as proof of the existence of a French anticolonialist fraternity who concerned themselves with their popular struggles. According to CONCP's Bulletin d'Information, there were already committees supporting their causes in Italy, Sweden, Norway, Brazil, and the United Kingdom, so the establishment of a Committee in France demonstrated that anticolonial solidarity was still growing. ${ }^{24}$ Indeed, the creation of the French support committee should not be understood as an isolated phenomenon; it formed part of a larger political context, characterized by the constant démarches of the many solidarity organizations that were established throughout Europe in roughly the same period, and whose networks and agencies often transcended national borders. ${ }^{25}$ Not that the committees created in Europe in the early 1960s constituted an entirely homogeneous movement: sources indicate the existence of diverging currents of ideas as well as competition between committees and also between some organisations in Africa and Asia, as Maurice Ferares (from a Dutch Committee) pointed out in a letter to Cabral in 1963. For example, according to the French activist Jean Mettas, the Angolan Action Group based in London, which had Baptist and Methodist religious influence, privileged support for the UPA (headed by Holden Roberto, who had a Baptist background), which competed with the MPLA to lead the Angolan independence struggle. ${ }^{26}$

While the birth of the French support movement was intimately related with the beginning of the armed struggle in Angola and subsequent international dynamics, the notion of anticolonial solidarity networks that used a variety of simultaneous strategies to influence public opinion had historically different ramifications and contexts. ${ }^{27}$ In the early 1960s, France's own colonial war in Algeria had a catalyst effect, reinforcing anticolonial solidarity, ${ }^{28}$ as evidenced by the bulletin Études Anticolonialistes. Fiches D'Information. The Études Anticolonialistes was an occasional newspaper, edited by P. Goldmann, which an autonomous group of anticolonial activists engaged with the Algerian war began to publish in Paris in November $1962 .{ }^{29}$ After the war, the group had shifted focus to other settings and the second issue, published in December 1962, was focused on the liberation movements of Portugal's African colonies. Some 
members of this collective also assisted the work of the Support Committee for Angola and the Peoples from the Portuguese Colonies. For instance, in 1964, Support Committee member Jean Mettas edited an issue of Études Anticolonialistes devoted to Guinean colonial history, resistance and liberation war. ${ }^{30}$

The true height of the solidarity campaign, however, would only take place almost a decade later, in the aftermath of the momentum of radicalisation ushered by the May 1968 protests. In December 1969, French activists instituted the Comité National de Soutien de la Lutte de Libération dans les Colonies Portugaises (CNSLCP), a selfprofessed autonomous collective which did not depend on any French political party. ${ }^{31}$ This committee included activists Gil Tchernia (Secretary-General), Maurice Gastaud (President and head of the Political Commission), Rolande Gastaud and Antonietta Haddad (editors-in-chief of the Bulletin Mensuel d'Information Économique et Politique and the CNSLCP - Bulletin D'Information, two publications aimed at informing French public opinion about Portuguese colonialism and the political and economic situation in African territories under Portuguese rule). ${ }^{32}$ The CNSLCP's main purpose was to bring together the efforts of all those in France who wished to support the three major liberation movements of the Portuguese colonies: MPLA in Angola, FRELIMO in Mozambique, and PAIGC in Guinea-Bissau and Cape Verde. ${ }^{33}$ In January 1970, Amílcar Cabral saluted the creation of this new committee with optimism: in a letter addressed to Gastaud, Cabral said he considered the organization a great victory for the French anticolonialist and anti-imperialist struggle to win over public opinion and so a victory for the African people in the struggle against retrograde Portuguese colonialism. ${ }^{34}$ The CNSLCP's first public meeting occurred in Paris, at Mutualité, on 18 March 1970. The purpose of this meeting was to outline further actions to be undertaken in France, to address the press and other groups capable of efficiently disseminating information about the liberation movements in Portugal's colonial territories and to persuade the French public to support them. ${ }^{35}$

This Committee was structured into different commissions, each charged with specific tasks concerning the recruitment of support from civil society. The aid they provided to the liberation movements was multiform and adapted in terms of both political support and concrete help. The political commission was to work in collaboration with other anticolonial solidarity groups, to participate in international forums, and to denounce the economic and political collaboration of the French and other governments with Portuguese colonialism and Western imperialist policy in 
Southern Africa. The economic and financial commission worked with the money collected from voluntary contributions, a crucial resource for commanding the printed word, supplying the costs of publishing information and purchasing and transporting materials like blood and other medical necessities to the liberation movements. It also raised funds for reconstruction programmes in the liberated areas. The informationpropaganda and press-archives commissions focused on delivering information about the liberation movements to the press in France and elsewhere in Europe, organizing press conferences with the movements' leaders, promoting debates on colonialism and the armed struggles in Africa and organizing informative public meetings to reinforce the criticism of the role and responsibility of the West, and the French Government in particular, in providing aid to Portugal's colonial wars. The pedagogical commission collected school supplies for the children's classes being held in the liberated areas. The sanitary commission supplied medical aid in the form of medicines, surgical instruments, vaccines and fresh blood. ${ }^{36}$

CNSLCP's Secretary-General, Gil Tchernia, played a crucial role in many of these processes. Tchernia, a major French anticolonial militant, wrote for Le Monde about the Guinean and Cape Verdean anticolonial revolution, supported Cabral's comrades in Paris and sent medical aid (fresh blood and medicines) to the PAIGC's guerrillas. At the time, Tchernia was a young medical assistant at the Gustave Roussy Institut in Villejuif, in the suburbs of Paris. A close friend with Cabral, he integrated a friendship network composed by the couple French-Cape Verdean Jeanine Moulin and Raoul-Jean Moulin (the well-known contemporary artist and art critic). ${ }^{37}$

\section{Cabral, the PAIGC and the branching out of anticolonial networks}

French anticolonial solidarity must be understood as the political agency of individual actors and sets of networks engaged (in groups or separately) in challenging and undermining a system of power; it was not a uniform project, neither homogeneously constituted nor oriented exclusively toward a single liberation movement. At the same time, these manifestations of anticolonial solidarity must be seen in a more localized context, characterized by the contact leftist intellectuals and activists in France cultivated with African revolutionary leaders or members of their movements. Through leveraging their intellectual prestige, some anticolonial activists 
came to assist - or cultivate relationships with - the liberation movements without the intermediation of any collective organization like the support committees.

Less than two months after the PAIGC initiated its armed struggle (on 23 January 1963), Amílcar Cabral gave a press conference in Paris, on 8 March. The conference was promoted by the Comité de Soutien à l'Angola et aux Peuples des Colonies Portugaises with the aim of informing French public opinion of the reasons for the shift from protest to armed struggle, namely the continuation of the colonial regime's arbitrary infliction of terror, exploitation, repression and denial of basic liberties. The intention was also to legitimise the PAIGC's struggle in the eyes of the international community, in light of the Portuguese Government's systematic refusal to respect article 73 of the UN Charter. Cabral did not justify the PAIGC's military action as an ordered principle of their fight, but rather as a dialectical consequence imposed upon the party on account of the Portuguese Government's unacceptable efforts to deny the people's self-determination. The PAIGC had explored all avenues and taken up armed struggle as a last resort. Framing the question in terms of the global political order, Cabral argued that the Portuguese war effort, begun in Angola and now ongoing in Guinea, was a 'disastrous crusade' in an epoch whose international consciousness demanded that all conflicts be resolved by means of negotiation, in a world that showed the continuation of colonialism to be incompatible with peaceful coexistence. For this reason, he stated, the problems in the Portuguese colonies and their urgent fight for independence should receive the utmost attention and support of the international community. ${ }^{38}$

The following year, on 14 May 1964, the Comité de Soutien à l'Angola et aux Peuples des Colonies Portugaises promoted another press conference in Paris with Cabral, gaining coverage in various French newspapers like L'Humanité (15 May), Libération (15 May), and Le Monde (16 May). The committee's chronicle states that Cabral delivered the speech in front of thirty journalists. ${ }^{39}$ Cabral also gave an interview to the highly-reputed French journalist Paulette Péju that was published on 16 May in the renowned French newspaper Libération. ${ }^{40}$ Péju was the author of two books on the Algerian war, edited and published in 1961 by the leftist publisher François Maspero. ${ }^{41}$ She was married to Marcel Péju, a French intellectual who between 1953-62 worked as the general secretary of Jean-Paul Sartre's famous magazine Les Temps Modernes. Marcel Péju was also a militant supporter of the liberation movements in the Portuguese colonies who maintained correspondence with Cabral in the early $1960 \mathrm{~s} .{ }^{42}$ 
In this political moment and context, Cabral held that Paris was the centre of the West. As French journalist Gérard Chaliand aptly put it, the Paris of this period was 'the European capital of anticolonialism'. ${ }^{43}$ The solidarity of the French committee represented, in Cabral's words, the support of the French people for the struggles of the PAIGC and other liberation movements. At this press conference, Cabral addressed the material and financial assistance provided by Portugal's Western allies that allowed it to maintain the wars in Africa. Here Cabral did not explicitly condemn the French Government's responsibility for supporting the Portuguese war effort, but rather ironically expressed many key ideas that conveyed the political purpose of his speech. For example, he asserted that it was not the world's ideological divide between Left and Right that mattered to the liberation movements; their sole concern was with who was against Portuguese colonialism and who supported it: 'It is the people's and their governments' attitudes towards our struggles that determine our attitude regarding these peoples and their governments. In the present moment as in the future, we must know clearly who are our friends and who are our enemies.' Ultimately, in a sarcastic formulation, Cabral declared that 'the example of France and its decolonization plan encouraged our people to fight' ${ }^{44}$ Here, his stealthy and tacit implication was that even with all the power of its military force, France had not been able to prevent the independence of Algeria, its former colonial territory. Cabral was so-subtly suggesting that the fate of Portugal and its colonies would be similar.

The press conference was a way to reach public opinion and acquaint French civil society with the African revolutionary leaders and the purpose of their struggles. Cabral knew that solidarity groups and individual anticolonial militants in Africa, in France and in other European countries had turned their focus toward the liberation movements of Portugal's African colonies. In this case, the press conference also served as a forum to increase Cabral's visibility and strengthen the image of his political leadership in the eyes of world public opinion. ${ }^{45}$ French anticolonialists knew that Cabral had a good political reputation at the time, as a consequence of his various published statements against Portuguese colonialism since 1960-1 and his interventions in international arenas, including the UN in December 1962, and at the Organisation of African Unity (OAU) in February 1964, when he demanded the recognition of the PAIGC as the only official liberation movement for the independence of Guinea-Bissau and Cape Verde. ${ }^{46}$ Indeed, beyond its strictly military activities, the PAIGC was 
conducting its struggle via different informational strategies capable of generating political effects.

In terms of recruitment and information distribution, since the early 1960 s the PAIGC and other movements could rely on the work of supporters and militant African students from the Portuguese colonies who were exiled in Paris. In June 1961, sixty such students had escaped from Portugal to France with the clandestine aid of the French Protestant service. ${ }^{47}$ The majority did not stay in France, but the exile linked some of those students to the Third-Worldism networks based in Paris. ${ }^{48}$ A number of PAIGC members nurtured contacts with other anticolonialists in Paris, and some of them received support from French leftist activists. For example, Pedro Pires, one of the African students that escaped to France and subsequently became a PAIGC member, maintained close relations with Gérard Chaliand, who went on to become one of the main French experts on Cabral's anticolonial revolution. Another Cape Verdean PAIGC member, Joaquim Pedro Silva (known as 'Barô'), was in Paris in the early 1960s, clandestinely housed and supported by the intellectual couple Denis Berger and Michèle Riot-Sarcey, two communist militants with links to the far-left newspaper La Voie Communiste. With the couple's assistance, Pedro Silva met other PAIGC members in Paris, such as the Cape Verdeans Alcides Évora (known as 'Batcha') and Abílio Duarte, who, upon leaving Paris, became the PAIGC's representative in Algiers. While in Paris, he had contact with Dulce Almada, another Cape Verdean PAIGC member who was then based in France and he later married. According to Roger Faligot, Abílio Duarte had close links with the famous Franco-American artist Joséphine Baker, who frequented the Parisian African militant milieu. In addition to these prolific connections, through the French anticolonial activist Georges Mattéi (a close friend of Chaliand), the prominent chemist Adolfo Kaminsky produced passports for PAIGC members and, with the passport he had made for him, established Amílcar Cabral's brother Luís in Paris. A member of the French Resistance during World War II, Kaminsky had previously forged identity documents for Jews. ${ }^{49}$

Besides these relationships, the liberation movements' political reputation in France can be observed through various indicators. First, in 1962 the Comité de Soutien à l'Angola et aux Peuples des Colonies Portugaises began to publish statements and reports, and to hold conferences to inform French public opinion about the anticolonial struggles in Africa and in Guinea-Bissau in particular. In 1963, for example, the committee devoted a special issue of its bulletin to a year of PAIGC struggles. 
Secondly, in December 1962, the Études Anticolonialistes brought studies of the liberation movements of Portugal's African colonies to the attention of the French public - their entire print run of six hundred copies sold out, which shows the kind of reception that publications on this theme were then having among some sectors of French civil society. ${ }^{50}$ The bulletin they issued in January 1964 was entirely dedicated to the war in Guinea-Bissau. In addition to detailing the historical and geographical coordinates of the colonial space in question, as a method of familiarizing the French reader with basic preliminary information about Guinea-Bissau, the document examined the political and cultural effects of Portuguese colonial policies and traces, while setting out a genealogy of resistance that positioned the PAIGC's struggles at the forefront of the modern emancipation processes. ${ }^{51}$ Thirdly, since the early 1960s Cabral maintained a close correspondence with anticolonial activists and was continually receiving words of political and moral support from French intellectuals with links to Third-Worldism and leftist groups, including the philosopher Jean-Paul Sartre, the editor (and later renowned filmmaker) Claude Lanzmann, the journalist couple Gérard Chaliand and Juliette Minces, the student (and later historian) Jean Mettas, the editor and film producer Catherine Dourgnon, the film director Mario Marret, the photographer Gilles Caron, the syndicalist Maurice Gastaud, and the geographer and historian Jean SuretCanale, among others. When Cabral was prohibited from entering in France, Professor Reine Accoce played an important role as one of the intermediaries between the communications from the Guinean leader to the French PAIGC's supporters. ${ }^{52}$ In short, Cabral and the PAIGC's struggle for the liberation were well-known and part of the political engagement of notable actors in French civil society.

\section{Informal networks and the engagements of individual actors}

The anticolonial solidarity networks were heterogeneous and operated both via coordinated collective actions and via a microphysics of interlocutions between individual actors in specific arenas. Their underlying informality was expressed both through the actors' bursts of enthusiasm and through the occasional dead-ends, giving the impression of a fluid process largely driven by goodwill, where projects and

priorities were constantly shifting. One such episode concerns Jean-Paul Sartre, ${ }^{53}$ who was then the Principal Director of one of the most prestigious publications of the French left-political and cultural scene of that period, the magazine Les Temps Modernes which 
he had founded in 1945, and Claude Lanzmann, who was a member of its editorial board. On 8 February 1961, Lanzmann wrote a letter addressed to Amílcar Cabral in Conakry in which he stated that all board members, and Sartre in particular, would like to count on a 'deepened, so as detailed as possible' article by Cabral, on the current problems of the liberation struggle in Guinea-Bissau and the original organization of his political party, for publication in Les Temps Modernes. Lanzmann wrote on behalf of the members of the magazine's committee that they were ready to support Cabral with all their might for the success of the heroic struggle of the people of Guinea. ${ }^{54}$ Cabral answered with enthusiasm. Aware of that magazine's reach, he considered that such an article would be a means to make his party's struggle more well-known and respected in the world. The constraints of the struggle permitting, Cabral promised to send a text as soon as possible. ${ }^{55}$ However, no such article was published in Les Temps Modernes. There is no record of his authorship in the index of the edited titles, at least until the end of the war and of Portuguese colonial rule in Africa, in 1974-5.

In turn, Jean Mettas' political activities bear witness to how the issue of GuineaBissau gained visibility on French public opinion. Mettas was a young French student of history and politics, and an anticolonial activist during the Algerian war of independence. After the war, he continued to campaign for other African liberation movements and became one of the founders and main protagonists of the Comite de Soutien à l'Angola et aux Peuples des Colonies Portugaises. Mettas maintained a close friendship and correspondence with Cabral, whom he first met in Dakar in $1962 .{ }^{56}$ In an article co-authored with Dan André Faber and published in Les Temps Modernes (November 1962), Mettas was one of the first French anticolonialists to publicize the history of Portuguese colonialism in Guinea-Bissau and the PAIGC's emergence as an independence movement. ${ }^{57}$ Mettas became a key disseminator in France of news from the PAIGC about developments in the struggle and where the fighting was taking place. According to Mettas (in a letter addressed to Cabral on 25 November 1962), informing French and European civil society about the war in Guinea was one of the tasks he adopted as a militant for the cause of that colony's liberation ${ }^{58}$. In the early $1960 \mathrm{~s}$, through the anticolonial networks to which he belonged, and which included French anticolonialists based in Algeria, Mettas approached Cabral for an interview about the PAIGC's struggle which, in August 1963, was published in the newspaper Révolution Africaine, founded in 1963 by the Algerian Front de Libération Nationale (FLN) in order to promote the African anticolonial revolutions. In 1964, Mettas published another 
article in France concerning Guinea's liberation war. ${ }^{59}$ His activities were not confined solely to the field of writing and distributing information: Mettas also organized the press conferences that Cabral gave in Paris in 1963 and 1964. These conferences' impact is vividly evoked in Mettas' own words to Cabral, reproduced in the Portuguese newspaper Diário da Manhã: 'Cabral produces himself in Paris ${ }^{60}$. Another field of activities in which Mettas applied himself since 1963 was the collection and delivery of medicines and tools for the treatment of wounded PAIGC guerrillas and civilian populations affected by combat. ${ }^{61}$

Another major distributor of information in Europe, and particularly in France, about the Guinean war was the journalist Gérard Chaliand. A member of a French anticolonialist network that supported the liberation struggles headed by the FLN in Algeria, Chaliand met Cabral in Conakry in 1962. Between 1963 and 1964, Chaliand worked in Algiers (in close proximity to the French lawyer Jacques Vergès) as Révolution Africaine's editor-in-chief. ${ }^{62}$ From 1963 onwards, Révolution Africaine became one of the foremost promotional platforms for the leaders and struggles of the liberation movements of Portugal's African colonies. It also went on to become a forum for the Portuguese opponents of the Estado Novo when an exiled Portuguese revolutionary front established its base in Algiers with the support of the newly independent Algerian Government. ${ }^{63}$ Cabral submitted an article for publication in Révolution Africaine in March 1963. ${ }^{64}$ Chaliand was also one of the first French authors to present the French public with a book analysing the progress of the Guinean liberation struggle, discussing its social, historical, geographical, and military context. The book, entitled Guinée "portugaise" et Cap Vert en lutte pour leur indépendance, was published in 1964 by François Maspero. According to Libertação, PAIGC's official newspaper, Chaliand's book represented the world's waking interest in the issue of Guinean independence and, consequently, the international prestige that the PAIGC's struggles had achieved in the eyes of others ${ }^{65}$. Chaliand wrote this book based on the data and references contained in reports provided to him by Cabral in Conakry. He only first visited Guinea-Bissau in May 1966, accompanied by combatants, having produced many reports for the French public on the PAIGC's main actions and the socioeconomic organization of the lives of the populations in the liberated zones. Chaliand's informative contributions stemmed directly from his on-location observations of the Guinean territories held by the guerrillas. ${ }^{66}$ During this peregrination, he was afforded an inside view of the armed struggle's organization and praxis. This privileged access 
inspired two texts published in 1966 and 1967, in the culturally and politically influential French periodicals Le Nouvel Observateur and Les Temps Modernes, respectively. Chaliand's book Lutte Armée en Afrique, in which he analyses the political strategy of the PAIGC guerrillas, in comparison with other guerrilla practices (like those from Cuba and other Latin American countries), was also published in France by François Maspero in $1967 .{ }^{67}$

Through his books and other news outlets, Gerard Chaliand contributed to the world's knowledge of, and thus the internationalization of, the Guinean struggle. This is another example of the efficacy of the transnational networks generated by Cabral in bringing the ongoing anticolonial revolution into contact with French civil society. Chaliand was presenting to French audiences what, in his own words, he considered to be the most consequential of the armed struggles in Africa since 1963 and the most highly structured popular military mobilization the continent had ever seen. ${ }^{68}$ On the basis of his close contact with Cabral, and the knowledge he acquired while embedded with the PAIGC guerrillas in the field, Chaliand went on to become one of the most important anticolonialist intellectuals in France. The records of various conferences and meetings organized by the solidarity groups in Paris and other European countries throughout the 1960s are telling with regard to Chaliand's reputation as an opinionmaker and interpreter of what was unfolding in Guinea, and other related topics. For example, in December 1967, the Portuguese League of Teaching and Popular Culture (a Paris-based Portuguese association that promoted conferences and debates on many political and cultural matters) organized a cycle of conferences entitled 'The great problems of our time', at the Foyer International on Boulevard St. Michel. The first of these conferences focused on the liberation struggles in Portugal's colonies and Chaliand was invited to chair the keynote speakers' discussion. In 1969, the Mouvement de Soutien aux Peuples de l'Angola et des autres Colonies Portugaises (an anticolonial support committee formed in Geneva, Switzerland, in 1968) invited Chaliand to deliver a speech on the subject of the anticolonial revolutions in Portugal's African colonies at a meeting in the Salle du Faubourg in Geneva, which is reported to have been a success. ${ }^{69}$ Furthermore, Chaliand is recorded to have been one of the speakers at a Paris meeting organized by the CNSLCP about the struggles against Portuguese colonialism, along with the British journalist Basil Davidson and the French journalist Robert Lambotte, who worked for the French newspaper L'Humanité, all of whom supported the PAIGC's struggle. ${ }^{70}$ In addition to this role, Chaliand's active support is evident in 
the delivery of medicines to PAIGC combatants, as verified in several items of correspondence on the subject that he exchanged with Amílcar Cabral. ${ }^{71}$

Likewise, the PAIGC's cause maintained the support of the Présence Africaine's editors, who, in March 1970, offered to publish the History of Guinea and the Cape Verde Islands, which, according to Cabral, his French friend Jean Suret-Canale was then writing. ${ }^{72}$ The communist militant Suret-Canale was an anticolonialist intellectual and an expert in African history and geography. In 1961, he published a book entitled Histoire de l'Afrique Occidentale, edited in France by Présence Africaine. Like Basil Davidson, Suret-Canale wrote on African history prior to the Europeans' arrival. In the words of Catherine Coquery-Vidrovitch, this made him one of the pioneers in France on the field of African studies. Between 1959 and 1963, he worked in Guinea-Conakry (Republic of Guinea) and, in collaboration with local writer and historian Djibril Tamsir Niane, wrote the first history of that country. After he returned to France, Suret-Canale became the head of research at the Centre National de la Recherche Scientifique (CNRS) from 1966 to 1974.

The liberation struggle also became known through the contributions of the many filmmakers who travelled to Guinea-Bissau to film episodes of combat as well as documentaries or short films about life in the liberated zones. A number of scholars have demonstrated that this audio-visual media was an important tool, used by the liberation movements in the Portuguese colonies to record their struggles and produce international propaganda. Since early on, Cabral used cinema to publicize his military and political cause. ${ }^{73}$ Between 1964 and 1973, he invited various foreign journalists and filmmakers to visit Guinea-Bissau and get to know the PAIGC's structure first-hand: to observe them in combat, as well as their military training and process of revolutionary consciousness; to verify the establishment of the new emancipatory structures (schools, peoples' warehouses for the exchange of food and other agricultural products); and to see the everyday routine of populations in the liberated regions. Cabral's political purpose was clear: once these witnesses were given the opportunity to share their direct experiences of the reality of the struggle, they would serve to publicize in their own countries the strength of Guinean anticolonial nationalism, the revolution's progress and the PAIGC's firm political legitimacy among the popular masses in the Guinean hinterland. 


\section{Cultural artefacts and the spread of information}

In coordination with Cabral and the PAIGC combatants, several French journalists and cineastes made documentaries to expose the reality of Guinea-Bissau's liberation war. The first of these documentaries, a short film entitled Lala Quema (1965), was directed by Mario Marret, a former member of the French resistance during World War II, a member of the French Communist Party and a supporter of the FLN's struggle in Algeria. Marret was then a director of some renown: in 1954, he won his first short film award, at Cannes. In the early 1960s, he became a friend of Gérard Chaliand as well as a member of a network of French intellectuals that took an interest in colonial issues, including François Maspero and Pierre Vidal-Naquet, among others. ${ }^{74}$ Marret went to Guinea-Bissau in 1964, the same year that Hubert Kintsher, a journalist from the German Democratic Republic, visited the Guinean territories controlled by the PAIGC. ${ }^{75}$ Marret's film Lala Quema reports on many aspects of the lives of combatants as well as those of the people in the liberated zones who worked the fields, attended political meetings, underwent military training, etc. In Paris, the wellknown French film editor Catherine Dourgnon also worked on Lala Quema. ${ }^{76}$

Lala Quema is an example of the transnational circulation of the PAIGC's message promoted by foreign anticolonial solidarity, starting with Guinea-Bissau twoo Francophone neighbours. In February 1965, the film was shown in Conakry as part of an official exhibition programme called Images of Our Life and Our Fight, organized by the PAIGC's Information and Propaganda Section, with the support of the GuineaConakry Government. Guinea-Conakry was one of the African countries that most assisted Cabral's independence struggle (it was there that the PAIGC established its headquarters and, on 22-23 November 1970, was attacked by Portuguese troops, an episode amply covered by the CNSLCP - Bulletin D'Information). ${ }^{77}$ In March 1965 , Lala Quema was exhibited in Dakar with the authorization of the Government of the Senegalese Republic. Dakar was in that period the destination of Cape Verdean and Guinean migrants, and where many factions that competed with the PAIGC were based, even if President Senghor's support for the struggle was neither stable nor without ambivalence. $^{78}$

The film's path also illustrates the obstacles posed by the Estado Novo's allies. When, in March 1965, Cabral was in the Netherlands to attend a public screening of Lala Quema in Amsterdam, the municipal authorities forbade the exhibition, although 
Herman Wigbold, the head of current affairs at the VARA-TV channel, then exhibited Lala Quema on Dutch television. ${ }^{79}$ In France, the film was also prohibited and confiscated by the police. According to Le Nouvel Observateur, the reason for this was that Lala Quema did not have the necessary 'censorship visa', or authorization. In 1964, the De Gaulle Government had issued a decree that non-commercial films would now need a 'censorship visa', previously required for commercial films only. This tool to ensure 'the protection of good custom' could also serve the purposes of political control. L'Humanité and Le Nouvel Observateur stressed that the French Government and the 'liberal' De Gaulle regime endeavoured to ensure the rigorous application of this decree particularly whenever the Gaullist political line was crossed, including with regard to sensitive issues related to black people. ${ }^{80}$

The Lala Quema episode showcases the French and Portuguese authorities' collaboration in restricting the actions of the PAIGC's French supporters. On 30 March 1965, the Comité de Soutien à l'Angola et aux Peuples des Colonies Portugaises announced the upcoming screening of Marret's film in the Paris-Ciné, with the presence of Amílcar Cabral to speak about the struggle's development in Guinea. Aware of this announcement, on 6 April, before the event, the Portuguese ambassador in France, Marcello Mathias, requested to the Quai d'Orsay the prohibition of the film's public screening, leading to its successful interdiction. ${ }^{81}$ This proves not only that the Portuguese authorities followed some publications of the PAIGC's supporters in France, but also that French diplomacy cooperated in restraining the liberation movements' public visibility, even if, as Victor Pereira argues, French actions against the Estado Novo's opposition were not linear or regular. ${ }^{82}$

In 1965, assisted by Isidro Romero, Mario Marret directed another short film on the Guinean struggle, Nossa Terra (1966). The film was presented in France and other countries, including Senegal and Cuba. Nossa Terra was widely displayed, referenced and otherwise used in various meetings organized by different French anticolonial solidarity groups. Less fruitfully, French filmmaker of Guadeloupean descent Sarah Maldoror directed in 1970 Des Fusils pour Banta, about a Guinean countrywoman involved in the PAIGC struggle. The film had been commissioned by the Algerian government to serve as a propaganda tool in the struggle against Portuguese colonialism, but that government confiscated the material from Maldoror because of her demands for full control over the final editing, so the film never arrived at the public scene. Maldoror, who was married to Mário Pinto de Andrade, was one of the pioneers 
of French anticolonialist cinema on the Portuguese colonies, being mostly known for her fiction films Monangambé (1968) and Sambizanga (1972), both about resistance against political repression in Angola and based on tales from Angolan writer Luandino Vieira $^{83}$.

In 1970, another team composed by three French filmmakers, René Lefort, Tobias Engel and Gilbert Igel, spent three months in Guinea-Bissau and produced the film Nô Pintcha. According to the PAIGC's own magazine, the three were the first external visitors to cross the liberated regions from North to South, from Senegal to Guinea-Conakry. ${ }^{84}$ Their film was shown and awarded a prize at the Hyères film festival in France, in 1971. ${ }^{85}$ As scholars Catarina Laranjeiro and Paulo Cunha have pointed out, Nô Pintcha was crucial to making the reality of the Guinean national liberation struggle known to the world; it portrayed an organized society, led by the PAIGC and with its own institutions and tools of citizenship. ${ }^{86}$

To grasp these films' international impact, one must consider the fact that they were shown and publicized at a time that coincided with the growing unpopularity of the Estado Novo's colonial wars, joining what had become a whole subgenre of documentaries on the Guinean revolution, a few of them even winning awards at international film festivals. ${ }^{87}$ Indeed, cinema became a prominent battlefield: in the 1960s, the Portuguese regime produced no less than twenty-one films on Guinea-Bissau (its most abundant period for films on this theme) and, since 1965, the Estado Novo had commissioned the French cineastes Jean-Noel Pascal-Angot and Jean Leduc to produce numerous documentaries for international commercial distribution, featuring panegyric images of the Portuguese colonies, to be shown at festivals and on television, as well as to organizations such as the NATO assembly. ${ }^{88}$ Additionally, French enthusiasts of the Estado Novo spread propaganda presenting dictator António de Oliveira Salazar as a ruler imbued by French culture who had brought order to Portugal and who was the guardian of the values of Western civilization, framing Portugal as an example of benign colonization. ${ }^{89}$

Cultural artefacts such as testimonials, photos, books, information bulletins, newspapers and films served, in France and elsewhere, to disseminate the PAIGC's struggle and to oppose the Estado Novo's official discourse. In June 1966, for instance, in a meeting with the UN Special Committee for Decolonization, in Algiers, ${ }^{90}$ in addition to Cabral's reports about the situation and development of the armed struggle in Guinea-Bissau, he shared accounts by some of the journalists and filmmakers in his 
entourage regarding the PAIGC's accomplishments in the liberated zones and battlefields, including those of Gérard Chaliand and the Russian journalist Oleg Ignatiev. ${ }^{91}$ Cabral also presented the documentaries Nossa Terra and Labanta Negro, made earlier that year by Mario Marret and the Italian director Piero Nelli, respectively. In France, the PAIGC's cause made itself noticed not just through mainstream newspapers, political journals and intellectual magazines (Partisans, Les Temps Modernes, Aletheia, Le Monde, L'Humanité, Libération, etc), but also through the Communiqués, an information sheet published by the PAIGC in Conakry and distributed in France by Cabral's local networks. French public opinion gained further access to this issue through the plethora of books, anticolonial papers and bulletins edited by individual militant authors or by the CNSLCP.

Like Cabral, the Support Committee used these artefacts as pedagogical tools in its solidarity campaigns. They served as a 'complément d'information' that accompanied public lectures, with the CNSLCP acknowledging that Nossa Terra was a particularly precious 'element and aid for [increasing] the knowledge of this struggle'. ${ }^{92}$ The first informative meeting organized by the French Committee in Paris, at Mutualité in 18 March 1970, involved the screening of Marret's film and the distribution of books, newspapers, brochures, photos and posters about the liberation struggle. Similar material was also distributed at the Maisons de Jeunes et de la Culture (Youth and Culture Houses), student residences, universities, and meetings of Portuguese deserters and migrants. ${ }^{93}$

Likewise, cultural events organized by anticolonial solidarity groups acted as public demonstrations of opposition to the Portuguese colonial wars and dictatorship. In July 1968, supporters of the Portuguese military deserters exiled in France organized an 'Anti-Colonial After-morning' in Paris, which included a screening of Nossa Terra among the main features. ${ }^{94}$ In 1 December of that year, various renown French performers participated in a solidarity gala at the Mutualité in support of the Portuguese people's struggle against the Estado Novo. According to the press, the Mutualité room was packed with students, workers, women and members of political parties and other organisations. ${ }^{95}$ The Mutualité was in the 60 s-70s the well-known rendezvous place of diverse political and cultural meetings. ${ }^{96}$ The gala was sponsored by a heterogeneous group of activists, anticolonial militants, political parties, support committees, progressive movements and far-left political groups, including, among many others, the Parti Socialist Unifié (PSU) - a New Left-oriented splinter party from the French 
Communist Party - and the Union Nationale des Etudiants de France (UNEF) - one of the most prominent youth organizations mobilized towards anticolonialism. ${ }^{97}$

French television also drew attention to this topic. In September 1966, French war reporters Michel Honorin and Philippe Dumez had already presented, at the programme Panorama, a piece entitled Guérilla en Guinée Portugaise, spotlighting the PAIGC's military training, liberation consciousness and confrontations in the bush, including interviews with the guerrillas. In November 1969, French journalists and producers Isidro Romero, Jose Dias, Jean Baronnet, François Ede and Jean François Chauvel released a further set of reportages about Guinea-Bissau. The documentary programme Point Contrepoint addressed the issue of Portuguese colonialism and its effects, emphasizing, on the one hand, the presence of migrants and Portuguese deserters in France and, on the other, the dictatorship and the theatres of the colonial wars. The documentary also included a speech by Amílcar Cabral as well as images from Guinea-Bissau's liberated zones and combat scenes. ${ }^{98}$

\section{Connected struggles and political strategies}

The rise of these solidarity initiatives occurred at the culmination of a decade when Third World struggles such as the Vietnam war, the Cuban revolution, the Algerian war, the collapse of the European colonial empires in Africa, and the influx of the anticolonialist and anti-imperialist ideas of African and Asian liberation movements, as well the world's bipolarization in the framework of the Cold War, had all contributed, according to Christoph Kalter, to the growth of the radical Left in France, ultimately influencing the May 1968 uprising. ${ }^{99}$ Members of these New Left groups began to appropriate the idioms of emancipation struggles in other regions of the world, and thus, as Salar Mohandesi argues, to translate foreign revolutionary struggles into a French domestic idiom. In this transnational context, May 1968 may be seen as one among many fronts of a worldwide anti-imperialist and anticolonial struggle, ${ }^{100}$ which explains why some of the elements of this heterogeneous French New Left sponsored the Support Committees and initiatives like the abovementioned solidarity gala.

Additionally, throughout the 1960s France became one of the main destinations for Portuguese migrants, political exiles, deserters and draft dodgers who fled Portugal to escape the military service (and, thus, the colonial wars). Their presence increased the indictments of the Salazar regime, with Portuguese newspapers edited in France 
critically addressing the wars in Africa while expressing support for the liberation movements' demands. ${ }^{101}$ Some of these Portuguese were close to the French Communist League, the Action Committees of May'68, the Proletarian Left and other radical left groups, including Trotskyist, Third-Worldist, Maoist and Marxist-Leninist factions. ${ }^{102}$ As a result, the liberation of Portugal's colonies was not just articulated with the critique of the Estado Novo's brand of fascism, but also with the most popular antiimperialist cause at the time, as Portuguese activists formed the Portuguese Commission of Solidarity with the Vietnam People. This collective organized, for example, an informative meeting about Vietnam with Portuguese migrants on 18 March 1967, where they collected funds; in 1968, they sent sanitary aid to the Vietnamese combatants. From Paris, they corresponded with the authorities of the Democratic Republic of Vietnam and sought to mobilise Portuguese migrants to participate in protests promoted by the National French Vietnam Committee. ${ }^{103}$ The connection between causes was made explicit in a Portuguese pamphlet distributed on the occasion of the campaign for peace in Vietnam, planned for 21 October 1967, in Paris, which stated that the participation of Portuguese workers and democrats in this protest fitted in with their efforts against the colonial wars in Africa. ${ }^{104}$ Notably, this kind of interrelation harkened back to Cabral's own statements in September 1962, when he had emphasized the Vietnamese struggle, resistance and courage as inspiration for all the oppressed peoples in fighting for liberty and independence. ${ }^{105}$

In the aftermath of May '68, Portugal's war effort gained unprecedented prominence among France's Portuguese community and in French civil society alike. According to Victor Pereira, it was in 1968 that the first specific reference to Portugal's colonial wars appeared in any of the magazines edited by Portuguese political exiles in France. ${ }^{106}$ Until December 1969, when the CNSLCP was founded, the Portuguese colonies - as the Committee later recognized - had mostly seemed 'a distant, and exotic affair' because 'the French democrats seemed to have other, more urgent concerns: Vietnam and the Middle East'. In part, this shift can be attributed to the existence of liberated zones, to the several Western journalists and filmmakers that visited Angola, Mozambique and Guinea-Bissau, reporting about them, and to the international visibility achieved by the liberation movements. ${ }^{107}$ In 1969, the issue gained a renewed topicality through the International Conference of Solidarity for the Peoples from Portuguese Colonies and Southern Africa, which took place in Khartoum (Sudan) between 18-20 January. The event, promoted by the Afro-Asian Peoples' Solidarity 
Organization and the World Peace Council in collaboration with the liberation movements, hosted 400 delegates from 64 countries. French solidarity was represented by actors from different backgrounds, such as René Parmantier (of the Christian Conference for Peace), Elisabeth Mathieu (Movement Against Racial Discrimination) and Madeleine Malefant (International Democratic Federation of Women), among others. Khartoum enacted a public trial 'of Portuguese colonialism and the imperialist forces who feed the colonial war with weapons and money'. The Conference's resolutions recommended the formation of national support committees and the mobilization of Western public opinion as primary tasks for the anticolonial solidarity groups. ${ }^{108}$

The need to translate French protests against the Estado Novo and in support of the liberation movements into connected struggles integrated in an evolving international solidarity was further emphasized by the writings of internationalist militants Olivier Petit and Claude Gabriel (the pen name of Claude Jacquin Gabriel), members of the Revolutionary Communist League in France. In 1970-2, they wrote and printed 'Stop sending arms to the Portuguese colonialists' and 'French imperialism'. The former text about transnational solidarity against Portugal's wars in Africa was published, in Portuguese, as a supplement of Rouge (a Communist League newspaper), edited by Charles Michaloux. ${ }^{109}$

More than interlinking causes, the internationalist impulse could be seen in the fact that the CNSLCP acted together with similar organisations beyond French borders. The main collaboration with other European anticolonial support committees was the International Conference for the Peoples from Portuguese Colonies, which took place in Rome between 27-30 June 1970. The French Committee was one of 15 European committees in a Meeting of the West-European Committees organized in the Netherlands between 28-30 March 1970 to prepare the Rome Conference. Besides the CNSLCP, different French solidarity groups worked in the Conference's organization, including the Anti-Apartheid Committee, the Movement Against Racism, Antisemitism and for Peace, the PSU and the French Communist Party, among others. About 177 mass organizations from 64 different countries participated in the event. ${ }^{110}$ In the aftermath, on 1 July, the anticolonial leaders Agostinho Neto (MPLA), Marcelino dos Santos (FRELIMO) and Amílcar Cabral met with Pope Paul VI, an episode that further internationalized their image and their demands. ${ }^{111}$ 
Mostly, however, activist collaboration took place at a national level. In October 1970, in the context of Zambian President Kenneth Kaunda's (then OAU's President-inOffice) visit to Paris, the CNSLCP collaborated with the Anti-Apartheid Committee and other organizations to condemn France's financial and military support of the Estado Novo's exploitation in Africa: they persuaded the Communist deputy Louis Odru to inquire and debate about this topic with the Foreign Affairs Minister Maurice Schumann, at the National Assembly; they wrote a statement to the National Assembly against French military support to Portugal and South Africa; on the occasion of Kaunda's press conference, the CNSLCP informed the OAU's President-in-Office about their activities and gave him some of their publications; they sent documents to the press to expose the arms delivered by the French Government to South Africa and Portugal. ${ }^{112}$ In fact, the PAIGC's own documents reported on arms, munitions and several war materiel provided to Portugal, as well as their countries' origins, including France and other NATO members. ${ }^{113}$

On 21 January 1971, in partnership with twelve other civil society organizations, the CNSLCP co-signed a letter to French Prime Minister Chaban Delmas criticising his government's ongoing support for the Portuguese colonial regime and the racist rulers of South Africa. The cosignatories requested that the French Government cease selling arms to Portugal, block NATO military aid to the Estado Novo, and withdraw the capital contributions of French companies toward the construction of the Cahora Bassa dam in Mozambique (an investment which they said ultimately served the interests of the South African Government, which was going to import the dam's electricity). ${ }^{114}$ These campaigns had some impact on the French diplomatic milieu during the Georges Pompidou presidency (1969-74). According to historian Amaral Lala, after Kaunda's visit French diplomacy announced a change, starting in 1971, to their supply policy of military materiel to Portugal. Some French authorities considered the diplomatic and military aid provided to the Estado Novo incompatible with France's desired image in Africa. Despite this concern, however, there was not enough political consensus and the change proved temporary: in the beginning of 1972, the French Government began to once again answer favorably to Portuguese military demands. ${ }^{115}$

On a parallel front, the CNSLCP collected voluntary contributions to provide financial, material, medical and sanitary assistance to the liberation movements, ranging from school supplies to medications, medical books and equipment, vaccines and blood, although the Committee's capacity to assist in this way was limited because it 
was contingent upon individual benevolence. According to the Committee's report, the collection work occurred at the last Saturday of each month and numerous Portuguese workers based in France were among the blood donors. ${ }^{116}$ It should be noted, however, that the French anticolonial solidarity was never monolithic, and the CNSLCP was not a unanimously accepted platform. For example, the French journalist Yves-Marie Choupaut, who sought to assist the liberation movements through the collection of French workers' blood, refused the intermediation of the CNSLCP because he considered it a collective of 'intellectuals and petty-bourgeois' ${ }^{117}$ The Secours Populaire Français (a French non-lucrative aid organisation) also supplied antibiotics to Guinea-Bissau. ${ }^{118}$

In ten months during 1970, according to the CNSLCP's Sanitary Commission, about 80 litres of blood were sent to Guinea-Bissau for use in the treatment of wounded military personnel and civilians. ${ }^{119}$ In 1971, Cabral asserted that the French friends of the movement were sending fresh blood to Guinea-Conakry by airliner every fifteen days. ${ }^{120}$ Blood collected in Paris was transported to the Solidarité hospital located in Boké, a region near the border with Guinea-Bissau. ${ }^{121}$ Cabral highlighted this particular form of support provided by the French anticolonial networks not just in order to publicly acknowledge the important role of the solidarity movement, but also to bring to the international community's attention the contradiction between the principles of liberty, equality and fraternity inscribed in France's national moto and the French Government's attitude toward the African struggles for national independence. Effectively emphasising the contrast between the attitudes of the French Government and of the solidarity networks, Cabral wryly observed in a press conference held in Algiers in April 1971: 'French blood presently circulates in the many veins of our combatants'. ${ }^{122}$

Another key source of aid - one that preceded the committee's foundation - was educational assistance. Scholars like Sónia Vaz Borges and Lars Rudebeck underline the emancipatory role of the education in the liberated areas. ${ }^{123}$ According to Libertação, 'in five centuries of Portuguese colonial rule, the colonialists' heavy heritage is a ratio of $98 \%$ illiterates.' Since 1964, the solidarity of foreign anticolonial organizations was therefore instrumental in supplying the teachers and students of the pilot schools established in the liberated zones and at PAIGC's military bases with crucial teaching and learning supplies (notebooks, pencil, pens, drawing materials, etc.). ${ }^{124}$ As Mustafah Dhada observes, the educational aid enabled the PAIGC to furnish 
schools with educational materials then badly needed by children with no access to such luxuries in villages; to carry out its avowed commitment to basic literacy as well as political education. ${ }^{125}$

Finally, the CNSLCP played a role in discussions of the aid provided to colonized African peoples. In November 1970, the General Conference of UNESCO argued for assistance programmes for refugees from colonized territories as well as for the people struggling to liberate themselves from colonial rule and all forms of apartheid. In collaboration with the OUA, UNESCO duly endeavoured to conceive concrete aid programmes. ${ }^{126}$ Knowing this, Cabral tried to ensure UNESCO's assistance in providing school books to the PAIGC-liberated zones in Guinea-Bissau by requesting the support of the OUA's Secretary-General Diallo Telli. ${ }^{127}$ This request, which was backed by the CNSLCP, opened up a debate about the role and actions of UNESCO concerning the African colonized peoples. Cabral then endeavoured to ensure the materialization of the UNESCO school manuals (reading, arithmetic, natural sciences and geography) ${ }^{128}$ with the help of CNSLCP's Maurice Gastaud, a renowned member of the French resistance in World War II, militant communist and unionist. Gastaud, who helped form the unionists at the Université Ouvrière Africaine (UOA) in GuineaConakry and maintained contact with the unionist movements of different African countries, had been in touch with Cabral since the early 1960s. Between 1969 and 1974, he worked at UNESCO as a permanent representative of the World Federation of Trade Unions, focusing on cultural concerns such as life-long education and human rights. With the sponsorship of UNESCO, Gastaud organized an exhibition of paintings and the revenue from works sold there was used to support the liberation movements in the Portuguese colonies. ${ }^{129}$

\section{Final considerations}

The PAIGC considered transnational anticolonial solidarity a way to integrate Guinea-Bissau's and Cape Verde's liberation struggle in a world history of the peoples fighting for freedom and emancipation. Transnational solidarity was a key part of the PAIGC's political language, to the point that the support from the world's anticolonialist organisations was a key theme included in the program for the formation of the PAIGC combatants. ${ }^{130}$ French solidarity played a role in fulfilling this vision. 
Despite the CNSLCP's prominence, French anticolonial solidarity with the liberation struggle in Portuguese colonies was not a homogeneous movement. The diversity of agents and operations translated into multiple informal networks and contacts between individual French anticolonial activists and members of the liberation movements; the cooperation of mass organizations; interventions on the basis of friendships, and the leveraging of the influence of political and cultural actors in order to increase the liberation struggles' visibility within French civil society. Mapping out the actions of support committees and other anticolonial actors can therefore prove revealing about the individual autonomy and political subjectivities of actors in these networks.

Overall, the committees' actions were conditioned by the lack of institutional status and the fact that their material and financial resources were limited and depended on the goodwill of voluntary donors. The effects were especially limited in terms of institutional high politics: on balance, their criticism and protests did not prevent the French Government from ultimately continuing to provide diplomatic and military support to the Estado Novo. In turn, through the mobilization of civil society actors, contributors and blood donors, French activists did provide various concrete forms of aid to the PAIGC's liberation struggle. Most notably, the distribution of information, meetings, debates, events and the crafting of propaganda material helped familiarize the public with the liberation struggle. This was achieved through a two-pronged communication strategy: on the one hand, activists approached the French press, as well as all the movements and organizations that could convey information; on the other, they organized public meetings at which committee members explained the historical context and conditions in which Portuguese colonialism was implanted in Africa, described the Angolan, Mozambican and Guinean liberation movements and then opened discussions to the audiences on the current situation and its international repercussions, complementing the discussion with films and publications. Thus, the CNSLCP, along with the individual agency of other anti-colonialist militants, brought Amílcar Cabral's revolution to French public attention, crucially contributing to making the PAIGC's struggle into a vastly multidimensional, transnational phenomenon whose different scales and branching connections stretch far beyond the national history of Portugal, Guinea-Bissau and Cape Verde. 


\section{Acknowledgements}

I would like to thank Rui Lopes and Jairzinho Lopes Pereira for their encouraging suggestions and incisive proofreading, the two anonymous reviewers for their helpful comments, my colleagues from the monthly Amílcar Cabral seminar at the NOVA University of Lisbon for their remarks, the project Amílcar Cabral: from political history to the politics of memory (PTDC/EPH-HIS/6964/2014) at NOVA University of Lisbon for all support, and, finally, to the audiences with whom I discussed different drafts of this paper, for their helpful feedback, namely in 29 September 2018 in GuineaBissau at the International Conference Memories and Legacies of the Liberation Struggles; in 5 April 2019 at the University of Coimbra (Portugal) in the $7^{\text {th }}$ Annual Encounter Europe and the World: Culture and Society in Europe Post-1945; in 25 April 2019 at the University of Lille (France) in the Journey on Media, Propaganda and Africans Decolonisation; and in 28 June 2019 at the University of Brighton, UK, in the International Conference The Radical Sixties: Aesthetics, Politics and Histories of Solidarity.

\section{Notes}

\footnotetext{
1 Amílcar Cabral, 'The development of the struggle', in Richard Handyside (editor and translator), Selected Texts by Amilcar Cabral. Revolution in Guinea. An African People's Struggle (Surrey: Stage 1, 1969), p.101.

2 A Prática Revolucionária - Unidade e Luta II, Obras Escolhidas de Amílcar Cabral, Textos coordenados por: Mário de Andrade (Lisbon: Seara Nova, 1977), 132-5.

${ }^{3}$ Peter K. Mendy, Amílcar Cabral: A Nationalist and Pan-Africanist Revolutionary (Athens: Ohio University Press, 2019), 156-65; David Fistein, 'The Diplomatic Achievements of Amilcar Cabral: A Case Study of Effective Leadership in a Small African State', in Baba G. Jallow (ed), Leadership in Colonial Africa. Disruption of Traditional Frameworks and Patterns (New York: Palgrave Macmillan, 2014), 69-100; Leopoldo Amado, Guerra Colonial \& Guerra de Libertação Nacional 1950-1974 (Lisbon: IPAD, 2011); Mustafah Dhada, Warriors at Work: How Guinea was Really Set Free (Colorado: University Press of Colorado, 1993).

${ }^{4}$ PAIGC - Mensagem - Relatório do camarada Amílcar Cabral aos quadros, combatentes e militantes do Partido, January 1970, 11-21; Libertação, December, 1964, 1-2; Conferência de imprensa de Amílcar Cabral em Paris, 8 March 1963, 2-3. Lisbon, Archive from Fundação Mário Soares.

${ }^{5}$ J. Alexander, J. McGregor, B-M. Tendi, 'The Transnational Histories of Southern African Liberation Movements: An Introduction', Journal of Southern African Studies, xliii (2017), 1-12; Hilary Sapire and Chris Saunders (ed), Southern African Struggles. New Local, Regional and Global Perspectives (Cape Town: University of Cape Town Press, 2013); K. J. Kuhn, 'Liberation Struggle and Humanitarian Aid: International Solidarity Movements and the 'Third World' in the 1960s', in Samantha Christiansen and Zachary A. Scarlett (ed), The Third World in the Global 1960s (New York/Oxford: Berghahn Books, 2013), 69-85; Toni Weis, 'The Politics Machine: On the Concept of 'Solidarity' in East German Support for SWAPO', Journal of Southern African Studies, xxxvii (2011), 351-367; Håkan Thörn, 'The Meaning(s) of Solidarity: Narratives of Anti-Apartheid Activism', Journal of Southern African Studies, xxxv (2009), 417-436.

${ }^{6}$ See the rich volume edited by Lena Dallywater, Chris Saunders, Helder Adegar Fonseca, Southern African Liberation Movements and the Global Cold War East. Transnational Activism 1960-1990 (Berlin: Walter de Gruyter GmbH, 2019); Corrado Tornimbeni, 'Nationalism and Internationalism in the Liberation Struggle in Mozambique: The Role of the FRELIMO's Solidarity Network in Italy', South
} 
African Historical Journal, 1xx (2018), 194-214; Natalia Telepneva, 'Mediators of Liberation: EasternBloc Officials, Mozambican Diplomacy and the Origins of Soviet Support for Frelimo, 1958-1965', Journal of Southern African Studies, xliii (2017), 67-81; Daniel Kaiser, 'Makers of the Bonds and Ties': Transnational Socialisation and National Liberation in Mozambique', Journal of Southern African Studies, xliii (2017), 29-48; Alexis D. Thevenod, Le dimension international des indépendances de la Guiné-Bissau et du Cap-Vert: 15 ans de relations extérieurs (1959-1974) (Master dissertation, Paris-IV Sorbonne, 2007); Pedro R. Mendes, Le Bloc Soviétique dans la sécurité et l'armée de la Guinée-Bissau (1969-1991) (Master dissertation, EHESS).

${ }^{7}$ Kim Christiaens, 'Europe at the crossroads of three worlds: alternative histories and connections of European solidarity with the Third World, 1950s-80s', European Review of History: Revue Européenne d'Histoire, xxiv (2017), 932-954; Christoph Kalter, The Discovery of the Third World. Decolonization and the Rise of the New Left in France, c.1950-1976 (Cambridge: Cambridge University Press, 2016); Kostis Kornetis, "Cuban Europe'? Greek and Iberian tiersmondisme in the 'Long 1960s', Journal of Contemporary History, L (2015), 486-487; Samantha Christiansen and Zachary A. Scarlett (ed), 'The Third World'; Robert Gildea, James Mark \& Niek Pas, 'European Radicals and the 'Third World'. Imagined Solidarities and Radical Networks, 1958-1973', Cultural and Social History, viii (2011), 449471.

8 Tramor Quemeneur, 'The French Networks Helping the Independence Movements of Portuguese Colonies. From the Algerian War to Third-Worldism', Afriche e Orienti, iii (2017), 85-100.

${ }^{9}$ Benjamin Stora, Appelés en guerre d'Algérie (Paris: Gallimard, 1997), 91.

${ }^{10}$ For more on the concept of solidarity: G. Florian, 'Introduction: writing the contemporary history of European solidarity', European Review of History: Revue Européenne d'Histoire, xxiii (2017), 837-853; W. Schmale, 'European solidarity: a semantic history', European Review of History: Revue Européenne d'Histoire, xxiv (2017), 854-873; S. Stjernø, 'The idea of solidarity in Europe', European Journal of Social Law, iii (2011), 156-176; N. Karagiannis, 'Solidarity Within Europe/Solidarity Without Europe', European Societies, ix (2007), 3-21.

${ }^{11}$ Melissa K. Byrnes, 'Diplomacy at the end of empire: envolving French perspectives on Portuguese colonialismo in the 1950s and 1960s', Cold War History, (26 May 2019), 1-15; Aurora Almada e Santos, A Organização das Nações Unidas e a Questão Colonial Portuguesa: 1960-1974 (Lisboa: Instituto de Defesa Nacional, 2017), 222-224; Daniel da Silva Marcos, Salazar e de Gaulle: a França e a Questão Colonial Portuguesa (1958-1968) (Lisboa: Ministério dos Negócios Estrangeiros, 2007); Amaral da Silva Lala, L'Enjeux Colonial dans les Relations Franco-Portugaises 1944-1974 (Ph.D. dissertation, Institut d'Etudes Politiques de Paris, 2007), 285; A. E. Duarte Silva, 'O litígio entre Portugal e a ONU (19601974), Análise Social, iii (1995), 37; https://undocs.org/S/RES/273(1969) (10.07.2019).

${ }^{12}$ Victor Pereira, A Ditadura de Salazar e a Emigração: O Estado Português e os Emigrantes em França (Lisboa: Temas e Debates, 2014) 379-384; José Augusto Pereira, O PAIGC perante o dilema CaboVerdiano [1959-1974] (Lisboa: Campo da Comunicação, 2015), 128; José Pedro Castanheira, Quem Mandou Matar Amílcar Cabral? (Lisboa: Relógio D’Água, 1999), 53-6.

${ }^{13}$ Víctor Barros, Campos de Concentração em Cabo Verde: As Ilhas Como Espaços de Deportação e de Prisão no Estado Novo (Coimbra: IUC, 2009), 132-41.

${ }^{14}$ Pedro Aires Oliveira, 'A descolonização portuguesa: o puzzle internacional', in Fernando Rosas, Mário Machaqueiro e Pedro Aires Oliveira (org), O Adeus ao Império: 40 Anos da Descolonização Portuguesa (Lisboa: Vega, 2015), 60-77; Luís Nuno Rodrigues, 'The International Dimensions of Portuguese Colonial Crisis', in Miguel Bandeira Jerónimo and António Costa Pinto (ed), The Ends of European Colonial Empires: Cases and Comparisons (Cambridge: Palgrave Mcmillan, 2015), 243-267; Bruno Cardoso Reis, 'Portugal and the UN: A Rouge State Resisting the Norm of Decolonization (1956-1974)', Portuguese Studies, ii (2013), 251-76.

${ }^{15}$ Rui Lopes, 'Accommodating and Confronting the Portuguese Dictatorship within NATO, 1970-74', The International History Review, xxxviii (2015), 505-526; Marvin R. Silva e Silva, A Descolonização da Guiné e Cabo Verde Perante o Cenário de Guerra Fria (Master dissertation, NOVA University of Lisbon, 2016; Rui Lopes, West Germany and the Portuguese Dictatorship 1968-1974. Between Cold Ward and Colonialism (London: Palgrave McMillan, 2014); Ana M. Fonseca and Daniel Marcos, 'Cold War Constraints: France, West Germany and Portuguese Decolonization', Portuguese Studies, ii (2013), 209-26; António Duarte Silva, A Independência da Guiné-Bissau e a Descolonização Portuguesa (Porto: Afrontamento, 1977).

16 S. Bosgra, 'A influência dos Movimentos de Libertação na opinião pública europeia', in Continuar Cabral: Simpósio Internacional Amílcar Cabral, Cabo Verde, 17 a 20 de Janeiro (Praia: Grafediro/PreloEstampa, 1984), 574.

${ }^{17}$ Le Monde Diplomatique, September 1961, 7; Le Monde, 11 March 1961. 
${ }^{18}$ Présence Africaine, xxxix (1961), 258.

${ }^{19}$ PAIGC - Memorandum à Assembleia Geral da Organização das Nações Unidas, pelo Bureau Político do PAIGC, Amílcar Cabral, Secretário Geral, 26 September 1961, 2; Memorandum enviado ao Governo Português pelo Partido Africano da Independência (Guiné e Cabo Verde), 1960, 3. Lisbon, Archive from Fundação Mário Soares.

${ }^{20}$ Présence Africaine, xxxix (1961), 258.

${ }^{21}$ Présence Africaine, xiv (1953), 221-40.

${ }^{22}$ Mário Pinto de Andrade. Uma entrevista dada a Michel Laban (Lisboa: JSC, 1997), 74-75, 109-111, 145.

${ }^{23}$ The Comité de Soutien à l'Angola et aux Peuples des Colonies Portugaises was based at: 42, Avenue du Parc de Montsouris, Paris XIV e, France. Angola Libre. Bulletin du Comité de Soutien à l'Angola et aux Peuples des Colonies Portugaises, i (January 1963), 2 and 27. Paris, Archive from La Contemporaine, Nanterre University.

${ }^{24}$ C.O.N.C.P. - Bulletin, v (November 1962), 18-19.

${ }^{25}$ Colin Bundy, 'National Liberation and International Solidarity', in Hilary Sapire and Chris Saunders (ed), Southern African Struggles. New Local, Regional and Global Perspectives (Cape Town: Cape Town University Press 2013), 212-228; Eduardo de Sousa Ferreira, Portuguese Colonialism from South Africa to Europe. Economic and Political Studies on the Portuguese Colonies, South Africa and Namibia (Göttingen, Levinstr: Aktion Dritte Welt, Freiburg i. Br., Lorettostr, 1972), 230-232.

${ }^{26}$ Jean Mettas, 19 April 1963; Maurice Ferares, 29 March 1963. Lisbon, Archive Fundação Mário Soares. For the West German branch of the solidarity movement, including its infighting, see Rui Lopes, West Germany and the Portuguese Dictatorship 1968-1974. Between Cold Ward and Colonialism (London: Palgrave McMillan, 2014), pp.66-73.

27 Michael Goebel, Paris, capital du tiers monde. Comment est née la revolution anticoloniale (19191939) (Paris: Éditions La Découverte, 2017).

${ }^{28}$ Claude Liauzu, Histoire de l'Anticolonialisme en France. Du XVIe siècle à nos jours (Paris: Armand Colin, 2007), 250.

${ }^{29}$ Études Anticolonialistes. Fiches D'Information, Supplément au n. ${ }^{\circ} 10$ - été 1963, 1-2.

${ }^{30}$ Études Anticolonialistes. Fiches D'Information, Janvier-Decembre (1964); Idem, xiii (Janvier 1964); Idem, ii (December 1962).

${ }^{31}$ The first address of the National Support Committee was at: 6 rue Emile Dubois - Paris 14e - 331-5425. C.C.P. From 1972 at: 69 rue Glacière - Paris 13 ème 7410-33; CNSLCP - Bulletin d'Information, ii (December, 1970), 1. Archive from Fundação Mário Soares.

${ }^{32}$ Bulletin Mensuel d'Information Économique et Politique. Angola, Mozambique, Guinée-Bissau et le Colonialisme Portugais, i (June 1972). Archive from Fundação Mário Soares.

${ }^{33}$ CNSLCP - Bulletin D'Information, 1972.

${ }^{34}$ Amílcar Cabral, Conakry; Muarice Gastaud, Paris, 29 January 1970. Archive from Fundação Mário Soares.

${ }^{35}$ CNSLCP - Déclaration (Conférence Internationale d'appui aux peoples des colonies portugaises, à Rome, 27-29 Juin, 1970), May 1970. Archive from Fundação Mário Soares.

${ }^{36}$ CNSLCP - Bulletin d'Information, ii (December 1970), 19-21.

${ }^{37}$ L'Humanité, 23 December, 2014; Faligot, 'Tricontinental', 63; Le Monde, 27 June 1970; Gil Tchernia, 1970. Lisbon, Fundação Mário Soares.

${ }^{38}$ Libertação, March 1963, 4; Conferência de imprensa de Amílcar Cabral em Paris, 8 March 1963. Lisbon, Archive from Fundação Mário Soares.

39 L'an Deux de la Guerre de Guinée, January - December, 1964, 14. Paris, Archive from La Contemporaine, Nanterre University.

${ }^{40}$ Libération, Paris, 16 May 1964.

${ }^{41}$ Paulette Péju, Ratonnades à Paris précédé de Les Harkis à Paris (Paris: Éditions La Découverte \& Syros, 2000).

${ }^{42}$ Amílcar Cabral. Marcel Péju, 10 December 1962. Lisbon, Archive from Fundação Mário Soares. More on Marcel Péju see: http://maitron-en-ligne.univ-paris1.fr/spip.php?article145748, notice PÉJU Paulette [née FLACHAT Paulette] par Gilles Manceron, version mise en ligne le 24 mars 2013, dernière modification le 17 octobre 2017; http://maitron-en-ligne.univ-paris1.fr/spip.php?article145648, notice PÉJU Marcel par Gilles Manceron, version mise en ligne le 18 mars 2013, dernière modification le 17 octobre 2017. (Accessed: 29.01.2019).

${ }^{43}$ In an interview given by Gérard Chaliand in Lisbon to Leonor Pires Martins and myself on 1 June 2018. 
${ }^{44}$ Conferência de imprensa de Amílcar Cabral em Paris, 14 May 1964. Archive from Fundação Mário Soares.

${ }^{45}$ Libertação, September 1963, 4.

46 PAIGC 1961-1974. I Documents (1962-1974). Archive from La Contemporaine; Memorando de Amílcar Cabral para U Thant (XVIII Sessão da Assembleia da ONU), Setembro, 1963; Memorando à XVIII sessão da Assembleia Geral das Nações Unidas, Outubro, 1963; Combattants anonymes de la cause de l'ONU, 12, Dezembro, 1962; Declaração de Amílcar Cabral na 1420 ${ }^{a}$ Sessão da IV Comissão da Assembleia Geral da ONU, 12 Dezembro, 1962; Relatório da audiência do Comité de Descolonização da ONU, 1962; Memorando à Assembleia Geral das Nações Unidas, 26 Setembro, 1961. Archive from Fundação Mário Soares.

${ }^{47}$ Charles R. Harper and William J. Nottingham, Escape From Portugal - The Church in Action. The secret flight of 60 African students to France (St. Louis, Missouri: Lucas Park Books, 2015).

${ }^{48}$ Roger Faligot, Tricontinental. Quand Che Guevara, Ben Barka, Cabral, Castro et Hô Chi Minh Préparaient la Révolution Mondiale (Paris: La Découverte, 2013), 58-65.

${ }^{49}$ Dulce Almada, 16 de March, 1961, Dulce Almada, Paris, 13 September 1961, Dulce Almada, Paris, 4 April 1961. Archive from Fundação Mário Soares.

${ }^{50}$ Études Anticolonialistes, ii (December 1962); 'Études Anticolonialistes, Supplément'; Angola. Comité de soutien à l'Angola et aux peuples des colonies portugaises (communiqués 1962-1965); Guiné "Portugaise" et iles du Cap-Vert - Bilan d'une année de lute - janvier-décembre - 1963, Lisbon, Fundação Mário Soares

${ }^{51}$ Études Anticoloniales, January 1964. Paris, Archive from La Contemporaine.

${ }^{52}$ Lusojornal, 4 December, 2017.

${ }^{53}$ Concernig Sartre and Third World see Noureddine Lamouchi, Jean-Paul Sartre et le Tiers Monde: Rhétorique d'un Discours Anticolonialiste (Paris: L'Harmattan, 1996).

${ }^{54}$ Les Temps Modernes, 8 February 1963. Lisbon, Archive from Fundação Mário Soares.

${ }^{55}$ Claude Lanzmann, Les Temps Modernes. Fundação Mário Soares.

${ }^{56}$ Jean Mettas, La Guinée portugaise au XXe siècle (Paris: Académie des Sciences D’Outre-Mer, 1984), 13-14; Hubert Deschamps, 'Jean Mettas (1941-1975)', Revue Française d'Histoire d'Outre-Mer, xli (1975), 5-6.

${ }^{57}$ Libertação, December 1962, 2.

${ }^{58}$ Jean Mettas, 25 November 1961. Lisbon, Fundação Mário Soares.

${ }^{59}$ Jean Mettas, 'La guerre en Guinée'; Idem, 'Notre lutte em Guinée, interview avec Amilcar Cabral', Révolution Africaine, 17 August 1963, 4-6.

${ }^{60}$ Jean Mettas, Comité de Apoio a Angola e aos Povos das Colónias Portuguesas, 20 March, 1963. Lisbon, Fundação Mário Soares.

${ }^{61}$ Ajuda em medicamentos. Jean Mettas, 1963; Comité de Apoio a Angola e aos Povos das Colónias Portuguesas. Comunica a passagem por Dakar de Dan, levando um contingente de medicamentos, 1963. Lisbon, Archive from Fundação Mário Soares.

${ }^{62}$ Gérard Chaliand, La Pointe du Couteau. Un apprentissage de la vie (Paris: Robert Laffont, 2011), 241267 and 307.

${ }^{63}$ Quemeneur, 'The French Networks', 90-3; Susana M. S. Martins, Exilados Portugueses em Argel. A FPLN das origens à rutura com Humberto Delgado (1960-1965) (Ph.D. dissertation, NOVA University of Lisbon, 2013); D. L. Raby, 'Portuguese Exile Politics: The 'Frente Patriótica de Libertação Nacional,' 1962-1973', Luso-Brazilian Review, xxxi (1994), 77-89.

${ }^{64}$ A. Cabral, '800.000 hommes en guerre', Révolution Africaine, 16 March 1963.

${ }^{65}$ Libertação, September 1964, 2-4.

${ }^{66}$ Chaliand, 'La Pointe', 307-313.

${ }^{67}$ The book was published in English in 1969 with an introduction by Basil Davidson. See: Gérard Chaliand, Armed Struggle in Africa With the Guerrillas in "Portuguese" Guinea, Introduction by Basil Davidson (New York: Monthly Review Press, 1969). Basil Davidson (1914-2010) was a British journalist and close friend of Amílcar Cabral who supported the PAIGC's cause and campaigned in the UK and across Europe for Guinea-Bissau's liberation.

${ }^{68}$ Gérard Chaliand, 'Les maquis de Guinée 'portugaise", Les Temps Modernes, April 1967; Le Nouvel Observateur, 13 July 1966; Idem, Guinée 'portugaise' et Cap Vert en lutte pour leur indépendance (Paris: François Maspero, 1964).

${ }^{69}$ MSACP, Genève, December 1969. Lisbon, Archive from Fundação Mário Soares.

${ }^{70}$ Fonds Vasco Martins. ARCH 0077/2. Paris, Archive from La Contemporaine, Nanterre University; Convite da Liga Portuguesa do Ensino e da Cultura Popular para uma conferência sobre a luta de libertação nacional das colónias, 19 December 1967. Lisbon, Fundação Mário Soares. 
${ }^{71}$ Chaliand, 29 November 1962; Gerard Chaliand, 4 Novembro 1962. Lisbon, Fundação Mário Soares.

72 Leitura do manual consagrado à história da Guiné e Cabo Verde, 23 de Março, 1970. Lisbon, Fundação Mário Soares.

73 Alexsandro de S. e Silva, 'Os esboços da nação guineense em Madina Boé (1968), de José Massip', Significação. Revista de Cultura Audiovisual, xlv (2018), 102-22; M. do C. Piçarra, 'Angola: (Re)Imaginar o Nascimento de uma Nação no Cinema Militante', Journal of Lusophone Studies, iii (2018), 168-194; G. Ros, 'Cinema on the Cultural Front: Filmmaking and the Mozambican Revolution', Journal of African Cinemas, iii (2012), 139-160; C. Andrade-Watkins, 'Portuguese African Cinema: Historical and Contemporary Perspectives 1969 to 1993', Ecrans d'Afrique, xiii-xiv (1995), 110-124.

${ }^{74}$ Chaliand, 'La Pointe', 220 and 314.

${ }^{75}$ Mario Marret, Rustrel, 3 de Augusto de 1965. Archive Fundação Mário Soares.

${ }^{76}$ Lalaquema, 6 December 1964. Fundação Mário Soares.

${ }^{77}$ CNSLCP - Bulletin, iii (March 1971), 14-6.

78 Julião Soares Sousa, Amílcar Cabral (1924-1973). Vida e Morte de um Revolucionário Africano (Coimbra: Edição do Autor, 2016).

${ }^{79}$ Projeção do filme "Lala Quema”, 16 July 1965. Lisbon, Archive from Fundação Mário Soares.

${ }^{80}$ Journal L'Humanité - Archives du Parti Communiste Français/Archives Départementales de la SeineSaint-Denis, Cote 2935 PER 177 pour l'édition du 08/04/1965; http://referentiel.nouvelobs.com/archives_pdf/OBS0022_19650415/OBS0022_19650415_005.pdf

(Accessed: 27.12.2018).

${ }^{81}$ A. da S. Lala, 'L’Enjeux', 394.

${ }^{82}$ V. Pereira, A Ditadura de Salazar e a Emigração. O Estado Português e os seus Emigrantes em França (1957-1974) (Lisboa: Temas e Debates, 2014), 371-412.

${ }^{83}$ See: https://www.tabakalera.eu/en/preface-des-fusils-pour-banta(26-10-2019); Maria do Carmo Piçarra, 'Cinema da Libertação: Luandino Vieira Filmado por Sarah Maldoror', in Francisco Topa and Elsa Pereira (ed), Colóquio de Luuanda a Luandino: Veredas (Porto: CITCEM and Afrontamento, 2015), 1916; José Luandino Vieira, La Vrai Vie de Domingos Xavier suivi de Le Complet de Mateus, traduction de Mário de Andrade et Chantal Tiberghien (Paris: Présence Africaine, 1971).

${ }^{84}$ A Libertação, June 1971; PAIGC Actualités, May 1971.

${ }^{85}$ A Libertação, June 1971; PAIGC Actualités, May 1971.

86 Paulo Cunha and erCatarina Laranjeiro, 'Guiné-Bissau: do cinema de Estado ao cinema fora do Estado', Rebeca, v (2016), 11.

${ }^{87}$ Silva, 'Os esboços', 104.

${ }^{88}$ M. do C. Piçarra, 'O império contra-ataca: a produção secreta de propaganda feita por estrangeiros para a projecção internacional de 'Portugal do ultramar', Media \& Jornalismo, xvi (2016), 43-59; P. Cunha, 'Guiné-Bissau: as imagens coloniais', in Catálogo da VII Mostra/V Simpósio Internacional Os cinemas dos países lusófonos (Rio de Janeiro: Edição do LCV, 2013).

89 Olivier Dard, Ana Isabel Sardinha-Desvignes, Célébrer Salazar em France (1930-1974. Du Philosalazarisme au Salazarisme Français (Bruxelles: Peter Lang, 2018); Lala, 'L'Enjeux', 222-23.

${ }^{90}$ Réunion du Comité Spécial de Décolonisation des Nations-Unies, Alger, 16-22 June 1966. Lisbon, Fundação Mário Soares.

${ }^{91}$ Libertação, June 1966, 2.

92 'CNSLCP - Déclaration', 1970, 4; Tarde Anti-Colonial. Lisbon, Fundação Mário Soares.

93 ‘CNSLCP - Déclaration', 1970, 4; CNSLCP - Bulletin, ii (December 1970), 19.

${ }^{94}$ Tarde Anti-Colonial. Lisbon, Fundação Mário Soares.

${ }^{95}$ A Voz do Imigrado, January 1969.

96 'Mário Pinto de Andrade. Uma entrevista', 120-1, 128-9.

${ }^{97}$ Gala de solidariedade, 1968. Lisbon, Fundação Mário Soares. On PSU and UNEF, see C. Kalter, 'Les damnés de 'Nanterre.' Extrême gauche, tiers-monde at années 68 en France', in Geneviève DreyfusArmand (ed), Les Années 68, un Monde en Mouvement. Nouveaux Regards sur une Histoire Plurielle, 1962-1981 (Paris: Syllepse, 2008), 68.

98 https://www.ina.fr/recherche/search?search=guinée+bissau (Accessed 22.07.2019); Informação sobre programa na televisão francesa com uma reportagem sobre Portugal. Lisbon, Fundação Mário Soares, Fundo Isabel Carmo/Carlos Antunes.

${ }^{99}$ C. Kalter, 'From Global to Local and Back: the 'Third World' Concept and the New Radical Left in France', Journal of Global History, I (2017), 115-136; Idem, 'Les damnés', 62-80.

${ }^{100}$ S. Mohandesi, 'Bringing Vietnam Home: The Vietnam War, Internationalism, and May '68', French Historical Studies, xli (2018), 219-251. 
${ }^{101}$ C. Volovitch-Tavares, 'Les Portugais dans la région parisienne depuis la fin de la Deuxième Guerre mondiale jusqu'en 1974', in Antoine Marès et Pierre Milza (dir.), Le Paris des étrangers depuis 1945 (Paris: Publications de la Sorbonne, 1994), 110-120; A. C. Clímaco Pereira, La Presse de l'Émigration Politique Portugaise, Analyse du Journal O Salto 1970-1974 (Master Dissertation, Université Paris VII, 1992). See also: J. P. Pereira, As Armas de Papel: Publicações Periódicas Clandestinas e do Exílio Ligadas a Movimentos Radicais de Esquerda Cultural e Política (1963-1974) (Lisboa: Temas e Debates, 2013).

102 A. F. Saraiva da Cunha, Os Comunistas Portugueses no Exílio (1960-1974) (PhD Dissertation, Lisbon University, 2015), 259-312; M. Cardina, Margem de Certa Maneira. O Maoísmo em Portugal: 19641974 (Lisboa: Tinta-da-China, 2011), 269-74.

${ }^{103}$ Silas Cerqueira; Comunicado sobre manifestação em Paris de apoio ao Vietnam; Documentos de apoio ao povo de Vietnam; Comunicado sobre sessão solene 'pela independência e a paz no Vietnam', patrocinada pelo Movimento Francês da Paz e pelo Comité Vietnam Nacional; Carta da Comissão Portuguesa de Solidariedade com o Vietnam dirigida à Delegação Geral do Governo da República Democrática do Vietnam. Lisbon, Archive from Fundação Mário Soares.

${ }^{104}$ Suplemento do n. ${ }^{\circ} 35$ de A Voz do Imigrado. Lisbon, Fundação Mário Soares.

105 Felicitações pela ocasião do aniversário da independência do Vietnam, 2 September 1962. Lisbon, Fundação Mário Soares.

${ }^{106}$ V. Pereira, 'L'engagement des exilés politiques portugais en France de 1958 à 1974', Latitudes, May 2001, 14.

${ }^{107}$ CNSLCP - Bulletin, ii (December 1970), 1. See also: Isabel G. Santos, O PAIGC e as Repercussões da Luta Nacionalista na Imprensa Ocidental (Master dissertation, ISCTE-IUL, 2010).

${ }^{108}$ FPLN Portugal, Khartum Encontro de Solidariedade Actuante, 20 August 1969; A FPLN em Khartum - Guiné, Angola, Moçambique, 18 January 1969.

${ }^{109}$ Cessai o fornecimento de Armas aos Colonialistas Portugueses, 1972. Recueil. Portugal: Colonies et Guerres de Libération. Documents divers/ 1954-1974. Paris, Archive from La Contemporaine, Nanterre University; Rouge, 27 January 1970.

110 Ibid., 3; Meeting of the West-European committees, supporting the liberation movements in the Portuguese Colonies. Lisbon, CIDAC, BAC - 0290, NC/57; Programa da Conferência de Roma, lista de participantes, June 1970. Lisbon, Fundação Mário Soares.

111 A. Milani and V. Russo, '1.' de Julho de 1970: O Encontro Entre Paulo VI e os 'Rebeldes' das Colônias Portuguesas de África: A Receção da Imprensa Italiana', Revista Polifonia, xxvi (2012), 218-34. 112 CNSLCP - Bulletin, iii (March 1971), 1-5; Idem, ii (December 1970), 8-9.

${ }^{113}$ PAIGC - Liste Partielle du Materiel de Guerre (Avions, Helicopteres, Bateaux, Armes, Munitions et Autres Equipements) Fourni au Portugal par l'OTAN et qu'il Utilize dans les Guerres Coloniales en Afrique, May 1971. Bissau, Archive from Instituto Nacional de Estudos e Pesquisas (INEP) of GuineaBissau.

${ }^{114}$ Bulletin d'Information - PAIGC, MPLA, FRELIMO, iii (March 1971), 1-5 and 17.

${ }^{115}$ Lala, 'L'Enjeux', 250-4.

${ }^{116}$ Mozambique, Angola, Guinée Bissao, Cap Vert, CNSLCP, ii (1973), 13.

117 João (Vítor João de Almeida e Sousa) e Fernanda (Saraiva de Carvalho), 2 March 1971. Lisbon, Archive from Fundação Mário Soares.

118 Journal L'Humanité - Mémoires d'Humanité /Archives Départementales de la Seine-Saint-Denis, Cote $243 \mathrm{~J} / 6$.

${ }^{119}$ CNSLCP - Bulletin, ii (December 1970), 19; Conférence de Presse tenue à Alger, le 28 Avril, 28 April 1971, 4. Lisbon, Fundação Mário Soares.

${ }^{120}$ PAIGC - Conférence de Presse tenue à Alger, 28 April 1971, 4. Lisbon, Fundação Mário Soares.

${ }^{121}$ CNSLCP - Bulletin, ii (December 1970), 20.

122 'Conférence de Presse', 4.

${ }^{123}$ Sónia Vaz Borges, Militant Education, Liberation Struggle, Consciousness: The PAIGC Education in Guinea Bissau 1963-1974 (Berlin: Peter Lang, 2019); L. Rudebeck, Guinea-Bissau. A Study of Political Mobilization (Uppsala: The Scandinavian Institute of African Studies, 1974).

${ }^{124}$ Libertação, December 1964, 2.

125 M. Dhada, 'Guinea-Bissau's Diplomacy and Liberation Struggle', Portuguese Studies Review, i (1995), 36.

${ }^{126}$ CNSLCP - Bulletin, ii (December 1970), 17-18.

127 UNESCO, Paris. Edição de manuais escolares. Amílcar Cabral, Conakry. Diallo Telli, Secretário Geral da OUA, 1970. Lisbon, Fundação Mário Soares.

${ }^{128}$ CNSLCP - Bulletin, ii (December 1970), 18. 
${ }^{129}$ Edição pela UNESCO de livros escolares para o PAIGC, 29 January 1970; Edição urgente livros instrução primária, 24 January 1970; M. Gastaud, União Geral dos Trabalhadores da África Negra, 15 May 1961. Lisbon, Fundação Mário Soares. More on Maurice Gastaud see: http://maitron-en-ligne.univparis1.fr/spip.php?article50660 (Accessed 14.01.2019).

${ }^{130}$ PAIGC - Escola Para a Formação de Combatentes, 1968, 16. Bissau, Archive from Instituto Nacional de Estudos e Pesquisas (INEP) of Guinea-Bissau. 